\title{
Labels and the Treatment of Animals: Archival and Experimental Cases
}

\section{W. Rajecki, Jeffrey Lee Rasmussen, and Heather D. Craft ${ }^{1}$}

INDIANA UNIVERSITY-PURDUE UNIVERSITY AT INDIANAPOLIS

The proposition that sheer labels or categories are important in people's reactions to the treatment of animals was supported by evidence from two sources. First, print archives showed that in the real world animals with a great deal in common such as (a) dolphins and tuna in the same nets; (b) cats and dogs, and pigs and goats in the same laboratories; and (c) native and feral species in the same parks are viewed or treated quite differently by humans. Second, original experiments were conducted wherein some hypothetical maltreatment of animals was held constant, but the animal label was varied over different respondents. Depending on the fictional maltreatment (hooking, shooting) and label (dog, cat, bird, fish, pig, goat) men and women respondents showed strong and systematic patterns of more or less tolerance for such treatment.

— "Tuna is a fun food," said Heinz [StarKist] vice president Ted Smyth. "If it's associated with the harassment and killing of a noble creature like the dolphin, that's not right" ("Swim with the Dolphins," 1990, p. 76).

— President George Bush celebrated election victory by shooting quail December 27 at the Lazy F Ranch near Beeville, Texas. "These aren't animals, these are wild quail," Bush said later... "I don't think I could shoot a deer," he added. "Quail — that's something else" ("Bush and Quail," 1989, p. 32).

In the domain of human relationships the sheer labeling or categorizing of individuals in terms of gender, race, or other social dimensions can be an important influence on perceivers' attitudinal and behavioral reactions to hypothetical or real persons. Further, one's own social category can influence one's reactions, as seen in phenomena such as ingroup/outgroup bias (cf. Jussim, Coleman, \& Lerch, 1987; Locksley, Borgida, Brekke, \& Hepburn, 1980; Messick \& Mackie, 1989; Park \& Rothbart, 1982; Rajecki, 
De Graaf-Kaser, \& Rasmussen, in press; Word, Zanna, \& Cooper, 1974).

It is the aim of this paper to demonstrate that the labels or categories by which people mentally sort nonhuman animals are also important influences on attitudinal and behavioral reactions. Certain evidence for this proposition already exists. For example, Arluke's (1988) ethnographic research in biomedical laboratories showed that particular animals could be simultaneously viewed as objects and pets. Depending on the category in which it fell, an animal's fate could be very different from others of its species. Categories identified by Arluke were "enshrined pet," "liberated pet," "saved pet," and "martyred pet" (see also Arluke, 1990).

Similarly, Herzog (1988) observed in an animal-research facility that there were categories of mice with different moral status in the view of humans. The "good mice" were subjects in research projects; they were protected by law and given care. The "bad mice" were same-species pests ranging free in the building; they were exterminated in unpleasant ways. Herzog (1991) has also commented on the moral dilemma inherent in the animal categories of "pet" and "pet food."

Extending the idea of different animals' moral standing, Midgley (1984) has argued that certain species gain in moral status as a consequence of interactions with humans.As Tannenbaum and Rowan (1985) see it, even if pigs are smarter than poodles we may owe something more to dogs because of our social contact with them. In terms of our own (human) social category, dogs are less alien than pigs. Indeed, there is some evidence that boys use a higher form of reasoning in solving moral dilemmas involving dogs and chimpanzees compared with those involving turkeys (Dunlap, 1989).

Animals can be assigned different moral statuses for purely political reasons. In discussing "speciesism," Singer (1977, p. 230) suggests that over the last century major animal welfare societies "lost interest in farm animals" out of caution about their standing as tax-exempt charitable organizations. Taken to extremes in ideology, animals can even have a more elevated moral status than people. Arluke and Sax (1992) have shown that in Nazi Germany there was touching concem for certain animals, and terrible antipathy for certain humans.

As noted, our thesis is that labels matter in attitudes and behavior. The goal of this project was to expand the extent of research on the effects of labels and categories in human-animal relationships. To this end we tried to be somewhat eclectic. Information was gathered in two general ways: (a) by compiling a narrative review of a variety of instances taken from archival sources, and(b) from our own controlled, empirical investigations. 


\section{Overvlew}

By "label" (or category) we mean everyday, generic titles such as dog, or cat, or bird, or fish. (Other labels could be tuna and dolphin, or quail and deer.) These concepts are based on rules of inclusion and exclusion. Some of the rules might be based on biology (species), as in the previous examples. Other rules might be based on other conventions or social constructions as in examples such as pet, or laboratory animal, or feral species, or native species. For the present purpose we do not attach more or less theoretical importance to the variety of rules in operation.

This is a study in two parts. We sought support for our thesis via two quite different levels of analysis.

\section{Archival Cases}

The first approach drew on the actual treatment or fate of various animals as recorded in popular and scientific archives. The print media offers a number of examples of people's differential attitudes and behavior toward labeled or categorized animals. These reports from the real world document human reactions under the press of mundane circumstances. A sample of a variety of instances is offered, drawn from the domains of commerce, research, and conservation.

\section{Experimental Cases}

However, whatever one gains in the validity and immediacy of historical evidence, one loses in experimental control and rigor. Therefore, our second approach capitalized on experimental methodology. Here, we created questionnaires that presented standardized stories of the hypothetical (fictive) maltreatment of animals by humans. In two studies the rather unfortunate fate of several animals was held constant, whereas the species - the animal label - was systematically varied across individual respondents. The purpose was to record a person's attitude toward the event. For the attitudinal index we took separate measures of people's affective (evaluative), behavioral (intentional), and cognitive (consequential) reactions with regard to particular animal labels. That is, the dependent variable in the experiments was tied to the so-called A-B-C, or tripartite theory of attitudes (cf. Breckler, 1984; Rajecki, 1990, Chapter 2). 


\section{Part 1: Archival Cases}

The archives in question were reports or entries from print and other media that came to hand. The order in which these cases is presented is arbitrary. In all cases the differential treatment of animals based on labels or categories was the result.

\section{Dolphins versus Tuna}

By April 1990, the three leading U.S. tuna canners announced that they would no longer purchase fish caught in nets that were dangerous to dolphins. This decision was prompted by consumer concem and public pressure. Recently, an estimated 100,000 or more dolphins had been killed annually in gill, purse-seine, or drift nets that are used to catch tuna. In 1988 environmental groups called for a boycott of canned tuna, and some schools and restaurants banned the fish from their menus (Davis, 1988; Silver, 1990; "Swim with the Dolphins," 1990).

It was observed that the pro-dolphin campaign was an unusual "environmental" movement. At the outset it had no natural constituency, unlike, for example, clean air. People had to be persuaded to be concerned. Indeed, this recent concern for dolphins was in contrast with the attitudes of earlier decades. For example, the original 1963 movie version of "Flipper" had star Chuck Connors' fishery-owning character say of threatening dolphins: "If they come, we'll kill them. We have no choice," (McKibben, 1992, p. 53). Also indicative of earlier attitudes is the 1954 film "Hell Below Zero," in which star Alan Ladd and others enthusiastically harvest whales with a harpoon cannon (see Maltin, 1991, p. 512).

As one observer put it, the pro-dolphin issue was one that could not be measured in dollars and cents, and had no obvious human benefits. "This [was] one just for the dolphins" ("Swim with the Dolphins," 1990). By extension, the city of Malibu, Califomia has granted citizenship to cetaceans (whales, dolphins, and porpoises), calling itself a "human-dolphin shared environment [to] improve the relationship between humans and cetaceans" (Zeman, 1992, p. 6).

Regarding netting, it is obvious that a vast number of tuna were killed along with the hapless dolphins. However, whereas reports often mentioned that the dolphins died of "drowning" little has been said of the final subjective experiences of the fish. When concern was expressed about trapping large numbers of tuna, it was not about any animal's well-being, but rather in terms of risking tuna's value as a fish stock (Tennesen, 1989; Wallace, 1991) Indeed, the tuna has been praised as an excellent 
game fish: after being hooked, "tuna never stop fighting” (Tennesen, 1989, p. 10). Even during the uproar over the netting issue, some forms of tuna were judged suitable for consumption by concemed people: "... [F]resh tuna steak is O.K. It was caught with a hook or a harpoon, not a net" (Silver, 1990, p. 62).

Figure 1 shows a supermarket, point-of-purchase ad seen in mid1990. It clearly illustrates the differential valuation of tuna and dolphins, and the reaction to the netting issue. Apparently, someone missed the irony of having an anthropomorphized tuna - possibly already in spring water - appear to herald the good news for dolphins.

\section{Dogs and Cats versus Pigs and Goats}

Military medical personnel learn to deal with low- velocity gunshot

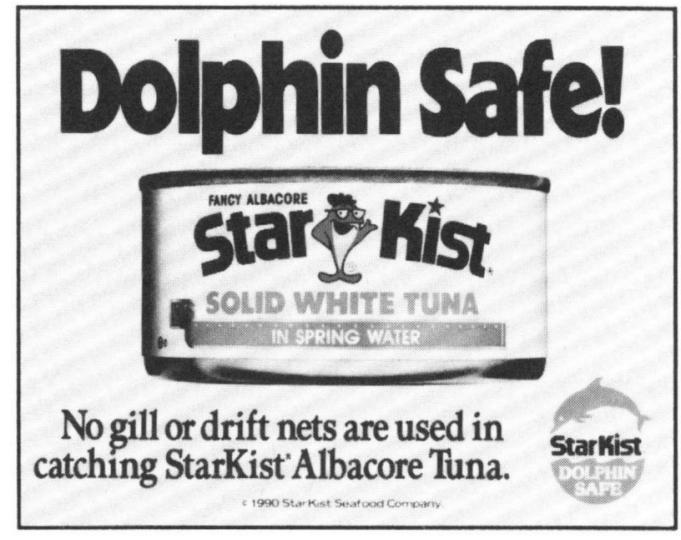

Figure 1. A supermarket, point-ofpurchase ad for a dolphin-safe canned tuna brand, reprinted with permission. wounds by training in civilian hospitals. In combat, however, wounds from highvelocity bullets are likely. The damage inflicted by high-speed missiles differs considerably from that from low-speed weapons, so special training programs are needed. One such program at the Uniformed Services University of the Health Sciences was temporarily halted in 1983 when the Secretary of Defense (Caspar Weinberger) reacted to protests that dogs might be used as targets. Congress imposed a restriction against the use of dogs or cats in wound research, and the Pentagon itself decided to forego the use of dogs and cats in weapons experiments. But by 1984 the general program was reinstated: other animals, namely pigs and goats, were approved for use (Fox, 1984). It has been reported that thousands of goats and pigs were shot in a number of government facilities ("Military Misdeeds," 1987).

\section{Puffins versus Gulls}

During the 19th century, puffins (a pelagic bird) nested in large numbers on islands off the coast of Maine. But by the turn of the century the effect of hunting was that the once 
abundant creatures had been virtually eliminated. Populations were further decimated by gulls that preyed on puffin eggs and hatchlings.

Modern attempts to re-establish colonies on certain islands have been extensive. Life-size wooden replicas of puffins have been set up as decoys, and taped puffin calls have served as lures for passing adults. Islands have also been seeded with puffin chicks that were hatched elsewhere. All of this seems to be working; there are reports of a small breeding colony on Eastem Egg Rock, and optimistic projections for Seal Island (Satchell, 1989; "Scientists Lure Puffins," 1992).

However, there is a catch to this program where other species were concemed. Those transplanted puffin chicks - unguarded by real adults - would be at great risk of predation by local gulls. To reduce such risk, in the late-1980s federal wildlife officials poisoned approximately 2,000 of the islands' herring gulls and black-backed gulls (Satchell, 1989).

\section{Native Species versus Feral Species}

Animals forcign to a particular locale are sometimes imported for commerce or recreation. If these animals are released or escape they might find a biological niche in the surroundings and survive as a feral species. Because population controls such as natural predators are absent or ineffective, feral animals may multiply rapidly.

Some feral species are seen as relatively benign. For example, in 1938 a small number of nutria - rodents native to Argentina - were imported to the state of Louisiana. Some escaped captivity, and the species flourished: it is estimated that by 1959 there were 20 million nutria in Louisiana alone. It is also thought that the nutria have caused no known extinctions, or serious effects to native species. The current nutria population is kept in check largely through commercial trapping (Conniff, 1989). Still, many feral species are viewed as anything but benign.

Early in this century several dozen European boars escaped from captivity in North Carolina. The animals interbred with barnyard pigs, and the hybrid's numbers increased. The hogs' diet is omnivorous, including tubers, bark, acorns, snails, snakes, small mammals, birds, and even fawns. They also eat the rare red-cheeked salamander, a native species. Hog rooting and wallowing are viewed as damaging to the region's habitat. Another trouble spot is in the Pacific, where wild pigs invaded the domain of a rare native bird called the Hawaiian honey creeper. The bird was deprived of both its food and habitat, and is now an endangered species (Schwartz, 1988). 
Certain attitudes toward feral swine can be summed up in President Carter's 1977 proclamation to purge the national park system of exotic (feral) species. A park official in the Smoky Mountains, was quoted as saying "wild hogs are the scourge of the Earth. They don't belong here and we don't want them" (Schwartz, 1988, p. 16). Some hogs in otherwise inaccessible areas are shot at night by park agents using spotlights mounted on guns.

Interestingly, this anti-swine sentiment on the part of some soon collided with proswine sentiment on the part of others. Residents in one area were furious at the proclamation and the proposed purge. This was because boars were the most popular big game in the area, and boar hunting was the source of considerable revenue in western North Carolina. The controversy resulted in a certain amount of vandalism and violence aimed at park officials (Schwartz, 1988).

Another feral species unwelcome at government sites is the exotic mute swan. Mr. Tom Whittendale, a Delaware biologist, was quoted as saying "A wildlife area should be for native wildlife, not for exotics... The mute swan has the status of, for example, a chicken" (Williams, 1989, p. 48). Human control of the mute swan population involves "egg shaking." A wildlife official shakes an incubated egg to scramble its contents and destroy its embryo. Shaken eggs are returned to the nest so that the swan pair will continue incubation of the intact but barren shells until it is too late to lay a second batch (Williams, 1989).

But if the mute swan is a danger to native species in the eyes of some, it is also a magnificent and beautiful beast in the eyes of others. The bird is said to inspire images of romance and elegance. Accordingly, wildlife biologists whose job it is to shake mute swan eggs have been vilified by local citizens, and made the target of hate mail (Williams, 1989).

\section{Summary}

These archival cases are interesting because of the physical proximity of the contrasted species. Dolphins and tuna are in the same nets; dogs, cats, pigs, and goats are in the same laboratories; puffins and gulls are on the same islands; and native and feral species are in the same parks. Nevertheless, they are viewed and treated very differently. Despite what they have in common, the fate of these animals as individuals or species depends greatly on the psychological attitudes of humans. 


\section{Part 2: Experimental Cases}

Based on some of the above archival illustrations, two experiments were designed with real-life events in mind. In one case we noted the comment by Silver (1990) that, even during the furor over netting, tuna steak was considered acceptable food since the animal was captured by hook or harpoon, and not by dolphin-threatening nets. Surely, this attitude reflects society's generally tolerant sentiment about the use of hardware in sport or commercial fishing. But whereas the impaling of fish for recreation or profit might be acceptable, what might be people's reactions to the equivalent hooking of other animal types?

In another case, we wished to gauge people's reactions to a situation like that reported by Fox (1984). Recall the matter of the violent sacrifice of animals in wound laboratories. How would people react to the systematic shooting of various animal types? This approach is reminiscent of Midgley's $(1984$, p. 15) use of the 1850 memoir of one R. Gordon Cummings to assess readers' moral response to the callous shooting of an elephant.

\section{Method}

\section{Independent Variables}

To answer these questions we wrote two parallel, fictional accounts: Story 1 and Story 2. These fictions described the fate of animals at the hands of humans. Story 1 was set in a farm; Story 2 was set in a laboratory. Both fictions involved a central character with which our subjects could identify. The stories read as follows:

STORY 1. I am a college student, and last summer I spent my vacation on my uncle's farm. At the back of his house was a large pond. We could tell that there was a stray fish in there because we could hear the splashing it made in the early morning. "I really would like to get a look at that fish," my uncle said.

So one day I went to town and got a right-sized hook from the tackle shop and some stuff for bait. Early the next morning I threw the baited hook out into the water and waited. Sure enough, the fish took the bait. When I felt it hit I jerked the line so hard that I drove the point of the hook up through the roof of its mouth and out its eye. I pulled the fish in to where I could see it, and it died in front of me in convulsions.

STORY 2. I am a college student, and last summer I spent my vacation as an intern 
at a military laboratory in Washington, DC. The unit I worked in used dogs. One project I volunteered for studied gunshot wounds. The experiments were necessary in order to train military medical personnel to deal with high-velocity gun wounds. My supervisor was interested in the effect of certain bullets on dogs.

I was given instruction on how to handle a particular gun. On the day of testing I adjusted the weapon and waited. When the dog was brought into the lab I aimed the weapon at it and pulled the trigger. The bullet hit it in the eye. I went over to the dog so I could see it, and it died in front of me in convulsions.

Each subject read a single story. For Story 1 (farm), different subjects read about a dog, cat, bird (chicken), or fish. The story was slightly amended in each instance to accommodate the species. Similarly, for Story 2 (lab), different subjects read about a dog, cat, pig, or goat. Because the stories contained an intentional confounding of animal type with setting and action, we planned to analyze them separately.

Subjects were drawn from undergraduate psychology classes at an urban public university. Since large classes were available for testing, we decided to employ convenience samples rather than structured samples. That is, instruments were distributed randomly to whomever happened to be in attendance at a test session. Given student characteristics at this university one would expect a female:male ratio of about 2:1. Further, given that there were four "cells" per gender (per story) a random sampling could produce unequal sample sizes across cells. To ensure at least substantial representation in each cell a fairly large sample was sought. Overall, 584 undergraduates were tested with one or another instrument.

\section{Dependent Variables}

Following each version of each story, a questionnaire was presented, as follows:

In this story the human character behaved in a certain way, and caused certain outcomes. What do you think of what he or she did? What kind of person is he or she? Please answer the following questions about the matter. Place a mark somewhere on each scale that indicates your reaction.

The same five questions were asked of every respondent. As noted, these questions were designed to represent the three components of the so-called A-B-C, or tripartite theory of attitudes: affect, behavior, and cognition. It has been argued that affect may be the most important or potent component in the A-B-C model (see Tesser \& Shaffer, 
1990). Therefore, three of the five questions were devoted to this component. Each question was presented in a bipolar format with a 13-point scale. Items 1-3 were about affect:

- The person in the story is: CRUEL/KIND

- The person in the story should be: PRAISED/PUNISHED

- The human behavior depicted in the event is: BIZARRE/NORMAL Next, Question 4 for the cognitive component was:

- How much did the animal in the story suffer? NO SUFFERING AT ALL/TERRIBLE SUFFERING

Item 5 for the behavior component was:

— Would you do what the person in the story did? NO, NEVER/YES, ANYTIME

\section{Design and Sample Sizes}

Story 1 (farm) and Story 2 (lab) served as the basis for separate investigations. Both studies involved a $2 \times 4$ factorial design. The two factors were between-subjects comparisons, and were defined by subject gender and animal type. Responses from men and women were considered separately because we expected women to have more concern for pain and suffering in animals (Gallup \& Beckstead, 1988).

In the investigation using Story 1, totals of 211 women, and 100 men were tested. For this study cell sample sizes for women ranged from 48-57; for men the range was 18-30. In the investigation using Story 2, totals of 182 women, and 91 men were tested. For this study cell sample sizes for women ranged from 43-47; for men the range was 17-30.

\section{Results}

For analysis of variance (ANOVA), the scores from the five questionnaire items were combined and treated as a globai attitude measure. For correlation and regression analysis, the values from the component items were compared with one another.

\section{Story 1 ANOVA}

Means and standard deviations for the global attitude measure (Questions 1-5) for Story 1 are shown in Figure 2. The 2 X 4 ANOVA yielded several relevant results. 
First, there was a main effect for subject gender, $F(1,303)=$ $17.45, p<.01$. This indicates that the hooking of the animal types generally evoked more tolerant responses from men compared with women. Next, there was a main effect for animal type, $F(3,303)=$ $107.12, p<.01$. For both genders there was far more tolerance for the hooking of a fish than the hooking of a dog, cat, or bird. (A Scheffé analysis [Keppel, 1991] showed a significant difference between ratings for the dog, cat, and bird compared with the fish, $F(3$, $303)=78.89, p<.01$. However, for this story the genders did not differ regarding the fate of the various animal types: there was no gender by animal type interaction, $F(3,303)=1.68, p>.05$.

\section{Story 2 ANOVA}

Means and standard deviations

for the global attitudinal measure (Questions 1-5) for Story 2 are shown in Figure 3. Several relevant results emerged from the ANOVA. Again, there was a significant main effect for subject gender, with men (compared with women) generally more tolerant of the shooting of animals, $F(1,265)=31.64, p<.01$. In this case, however, there was a nonsignificant main effect for animal type, $F(3,265)=2.43, p>.05$. As is evident in Figure 3, there was a strong gender by animal type interaction, $F(3,265)$ $=6.03, p<.01$. A subsequent effects analysis (Keppel, 1991) of this interaction 


\begin{tabular}{|c|c|c|c|c|}
\hline \multicolumn{5}{|c|}{$\begin{array}{l}\text { Table } 1 . \\
\text { Intercorrelations Between Questions } \\
\text { for Story } 1 \text { and Story } 2\end{array}$} \\
\hline Question & 2 & 3 & 4 & 5 \\
\hline \multicolumn{5}{|c|}{ Story 1 (farm, $n=311$ ) } \\
\hline $\begin{array}{l}\text { 1. Kind } \\
\text { 2. Praised } \\
\text { 3. Normal } \\
\text { 4. No suffering } \\
\text { 5. Yes, anytime }\end{array}$ & .78 & $\begin{array}{l}.75 \\
.71 \\
-\end{array}$ & $\begin{array}{l}.41 \\
.47 \\
.45 \\
-\end{array}$ & $\begin{array}{l}.69 \\
.67 \\
.69 \\
.38 \\
-\end{array}$ \\
\hline \multicolumn{5}{|c|}{ Story 2 (lab, $n=273$ ) } \\
\hline $\begin{array}{l}\text { 1. Kind } \\
\text { 2. Praised } \\
\text { 3. Normal } \\
\text { 4. No suffering } \\
\text { 5. Yes, anytime }\end{array}$ & $\frac{.68}{-}$ & $\begin{array}{l}.57 \\
.49 \\
-\end{array}$ & $\begin{array}{l}.37 \\
.40 \\
.32 \\
-\end{array}$ & $\begin{array}{l}.58 \\
.50 \\
.55 \\
.31 \\
-\end{array}$ \\
\hline $\begin{array}{l}\text { NOTE: The ques } \\
\text { bipolar scales; th } \\
\text { question column } \\
\text { table are significe }\end{array}$ & $\begin{array}{l}\text { stions } \\
\text { e posit } \\
\text { All } \\
\text { ant at }\end{array}$ & v & $\begin{array}{l}\text { lere } \\
\text { list } \\
\text { tion }\end{array}$ & $\begin{array}{l}\text { sing } \\
\text { the } \\
\text { the }\end{array}$ \\
\hline
\end{tabular}

indicated that men showed a significant difference in ratings assigned to animal types, $F(3,87)=$ 5.86, $p<.01$, but women did not show such an effect, $F(3,178)=$ $1.17, p>.05$.

\section{Correlation Analysis}

The intercorrelations of the five attitudinal questions from Story 1 and Story 2 are shown in Table 1. All the coefficients in the table are significant with $p<.01$. Where multiple measures are available, it would be expected that components would correlate more highly with themselves than with other components (Kothandapani, 1971). Responses to the three items aimed at affect (\#s 1-3) generally did show the highest intercorrelations.

Further, the three affect items all correlated well with the index of behavior (\#5). Somewhat weaker associations were found between the measure of cognition (\#4) and the other measures.

\section{Regression Analysis}

In a stepwise hierarchical regression analysis, Question 5 (behavior) was used as the dependent variable. Regarding Story 1 (farm), for the first step behavior was predicted with the cognition item alone. For the second step behavior was predicted with the cognition item plus the three affect items. The variance accounted for in Question 5 by the cognition item was $14.05 \%(p<.01)$, and variance explained by the cognition item plus the affect items was $56.15 \%$. The addition of the affect items significantly increased predictability $(p<.01)$.

Regarding Story 2 (lab), the variance accounted for in Question 5 by the cognition 
item was $9.20 \%(p<.01)$, and by the cognition item plus the affect items $41.64 \%$. The addition of the affect items significantly increased predictability $(p<.01)$.

\section{Discussion}

\section{Archival Cases}

People's differential views on the treatment of animals seen in the sample of archival cases possibly stem from a complex and strong web of values. In many of the cases we suspect that one could apply the social psychologists' point about "groupness" (ingroup/outgroup bias), or Midgley's (1984) point about the moral status of animals with which we humans interact. Dolphins are mammals, "our" kind of animal. Dogs and cats are "our" kinds of companions, and for U.S. citizens native species are definitely "ours." Puffins and gulls are both "ours," of course, but at the moment the premium is on the more photogenic puffin (see also Lavigne, 1978, on this point).

\section{Experimental Cases}

The results from the experimental cases are in line with this reasoning. Companion animals were generally associated with the least tolerance for maltreatment. Further, a respondent's own social category was certainly influential in the ratings of the events in the stories. Across the board, men were more tolerant of hooking and shooting than were women,

For Story 1, both genders were intolerant of the hooking of anything but the fish. Apparently, the hooking of a dog, cat, or bird was simply incongruous to respondents, yet this treatment was seen as appropriate where a fish was concerned. The means and standard deviations of the fish histograms in Figure 2 show that many respondents were highly tolerant of this activity.

For Story 2, men were generally more open to the shooting of pigs and goats than dogs and cats. Interestingly, however, women showed lower tolerance of the shooting of any of the species identified here. This may have occurred because guns are associated with hunting, a male-dominated sport. Another possibility is the fact that the setting was a military wound laboratory, and participation in armed combat is still largely closed to women in this society. Indeed, in future research of this sort it may be fruitful to have respondents guess or infer the gender of the characters in the stories. Results might further illuminate sex-linked patterns in human-animal relations.

Other noteworthy information from the experimental cases comes from the 
correlation and regression analyses. Although the number of questions we used was small, there was the consistent finding that the affect items were most strongly associated with, or more strongly predictive of the behavior item. While the cognitive item did explain a significant amount of the variance in responses to the behavior item, it was the weaker component. For the moment this suggests to us that what people feel about animal maltreatment may be far more important than what they think about maltreatment.

In closing, future work on labels and categories should look further into the mental structures or schema by which humans sort animal species, including their own. A simple (Cartesian) framework would be that all humans are in one category, and all animals in another. But we think this is a naive view. Animals as individuals take on moral status as a consequence of their admission to human networks and value systems. As someone said, companion animals are not like family members, they are family members (cf. Barker \& Barker, 1988; Berryman, Howells, \& Lloyd-Evans, 1985). Special animals are probably in special categories.

\section{Note}

1. Correspondence should be sent to D. W. Rajecki, Department of Psychology, IUPUI, 1125 E. 38th Street, Indianapolis, IN 46205-2810. This research was supported in part by a Department of Psychology SPUR grant to the third author.

\section{References}

Arluke, A.B. (1988). Sacrificial symbolism in animal experimentation: Object or pet? Anthrozoos, 2, 98-117.

Arluke, A. (1990). Moral elevation in medical research. Advances in Medical Sociology, 1, 189-204.

Arluke, A., \& Sax, B. (1992). Understanding Nazi animal protection and the Holocaust. Anthrozoos, 5, 6-31.

Barker, S. A., \& Barker, R. T. (1988). The human-canine bond: Closer than family ties? Journal of Mental Health Counseling, 10, 46-56.

Berryman, J. C., Howells, K., \& Lloyd-Evans, M. (1985). Pet owner attitudes to pets and people: A psychological study. Veterinary Record, 117, 659-661.

Breckler, S. J. (1984). Empirical validation of affect, bchavior, and cognition as distinct components of attitudes. Journal of Personality and Social Psychology, 47, 1119-1205.

Bush and quail. (1989, April). Animals' Agenda, p. 32. 
Conniff, R. (1989, December-January). Keeping an immigrant in check. National Wildlife, pp. 42-44.

Davis, A. (1988, November 14). The slaughter of dolphins. The Nation, pp. 486-488. Dunlap, J. J. (1989). Moral reasoning about animal treatment. Anthrozoas, 2, $245-258$. Fox, J. L. (1984). Ban on shooting animals for research is lifted. Science, 223, 568569.

Gallup, G. G., Jr., \& Beckstead, J. W. (1988). Attitudes toward animal research. American Psychologist, 43, 474-476.

Herzog, H. A., Jr. (1988). The moral status of mice. American Psychologist, 43, 473-474.

Herzog, H. A., Jr. (1991). Conflicts of interest: Kittens and boa constrictors, pets and research. American Psychologist, 46, 246-248.

Jussim, L., Coleman, L. M., \& Lerch, L. (1987). The nature of stereotypes: A comparison and integration of three theories. Journal of Personality and Social Psychology, 52, 536-546.

Keppel, G. (1991). Design and analysis: A researcher's handbook. Englewood Cliffs, NJ: Prentice Hall.

Kothandapani, V. (1971). Validation of feeling, belief, and intention to act as three components of attitudes and their contribution to prediction of contraceptive behavior. Journal of Personality and Social Psychology, 19, 321-333.

Lavigne, D. M. (1978). The harp seal controversy reconsidered. Queen's Quarterly, $85,377-388$.

Locksley, A., Borgida, E., Brekke, N., \& Hepburn, C. (1980). Sex stereotypes and social judgment. Journal of Personality and Social Psychology, 39, 821-831. Maltin, L. (1991). Movie and video guide 1992. New York: Signet.

McKibben, B. (1992, March 9). What's on? The New Yorker, pp. 40-42, 44-47, 50-56, 63-80.

Messick, D. M., \& Mackie, D. M. (1989). Intergroup relations. Annual Review of Psychology, 40, 45-81.

Midgley, M. (1984). Animals and why they matter. Athens, GA: University of Georgia Press.

Military misdeeds. (1987, June). Animals' Agenda, p. 24.

Park, B., \& Rothbart, M. (1982). Perception of out-group homogeneity and levels of social categorization: Memory for the subordinate attributes of in-group and out-group members. Journal of Personality and Social Psychology, 42, 1051-1068. 
Rajecki, D. W. (1990). Attitudes (2nd ed.). Sunderland, MA: Sinauer Associates. Rajecki, D. W., De Graaf-Kaser, R., \& Rasmussen, J. L. (in press). New impressions and more discrimination: Effects of individuation on gender-label stereotypes. Sex Roles.

Satchell, M. (1989, August 7). Man to puffins: Please come back and stay. $U S$.

News \& World Report, pp. 51-52.

Schwartz, D. M. (1988, June-July). Hog havoc. National Wildlife, pp. 14-17.

Silver, M. (1990, April 2). Tuna sandwiches and dolphins. U.S. News \& World

Report, p. 62.

Singer, P. (1977). Animal liberation. New York: Avon Books.

Scientists lure puffins back to U.S. (1992, January-February). International Wildlife, p. 28.

Swim with the dolphins. (1990, April 23). Newsweek, p. 76.

Tannenbaum, J., \& Rowan, A. N. (1985). Rethinking the morality of animal research.

Hastings Center Report, 15, $32-43$.

Tennesen, M. (1989, April-May). No chicken of the sea. National Wildlife, pp. 10-13. Tesser, A., \& Shaffer, D. R. (1990). Attitudes and attitude change. Annual Review of Psychology, 41, 479-423.

Wallace, C. (1991, March-April). A slaughter continues on the high seas. International Wildlife, pp. 42-43.

Williams, W. (1989, February-March). The dark side of a classic beauty. National Wildlife, pp. 42-48.

Word, C. O., Zanna, M. P., \& Cooper, J. (1974). The nonverbal mediation of selffulfilling prophecies in interracial interaction. Journal of Experimental Social Psychology, 10, 109-120.

Zeman, N. (1992, January 20). Citizen flipper. Newsweek, p. 6. 